\title{
Harmonising the City: Music, Multiculturalism and The Muses' Magazine in Brisbane
}

\author{
Patrick Buckridge
}

Brisbane in the 1920s certainly had its tense moments, but what struck me most forcibly in browsing the local newspapers from the period was how successfully political and social conflicts were absorbed into the peaceful, civil and lawabiding fabric of Brisbane life. World-altering events like the Russian Revolution, the Armistice and the Treaty of Versailles, the Irish Troubles and the rise of Mussolini were reported and discussed in the press and elsewhere, but matters seldom went further than that despite the real potential - given the presence of significant Russian, German, Irish and Italian minorities in the city's population - for 'imported' tensions. Even the momentous political developments that occurred in Brisbane in the early 1920s, when the state government's efforts to secure foreign loans were sabotaged by an opposition-funded delegation to London, and the Premier, EG ('Red Ted') Theodore, forced the parliamentary upper house to terminate its own existence, failed to polarise or fracture the community to any significant degree. ${ }^{1}$

In my view, the civility and stability that seem to have characterised Brisbane society in the 1920s should not to be regarded (as they tend to be) as a passive state of resistance to change. Rather, they should be seen as a positive achievement in their own right, the active creation of a liberal polity that managed to balance a high level of inter-class cohesion and social harmony with a significant degree of ethnic and religious diversity. Things could certainly have been otherwise. Small as it was by comparison with Sydney and Melbourne - Brisbane's population grew from 200,000 to 300,000 in the course of the decade ${ }^{2}-$ the city could easily have been the scene of political conflict, industrial confrontation and inter-ethnic violence. During and immediately after World War I, it was. Then it stopped happening - why?

I believe several factors - economic, political and cultural - underpinned this achievement. They include a buoyant state economy, a strong and (at least in the first half of the decade) moderately progressive Labor government, two culturally enlightened, politically compliant and popular state governors (Sir Matthew Nathan and Sir John Goodwin), a Catholic archbishop (James Duhig) without much interest in parliamentary politics - or Irish politics, for that matter - and a proliferating network of cultural and ethnic organisations. This last factor provides the focus of this article. 
It is a surprising fact that the following organisations were all established in Brisbane during the 1920s:

the Lyceum Club (1919)

the Queensland Authors and Artists Association (1921)

the Dickens Fellowship (1921)

the Brisbane Shakespeare Society (early 1920s)

the Brisbane Repertory Theatre (1925)

L'Alliance Française (Brisbane chapter, 1926)

La Società Dante (Brisbane chapter, 1926) 3

El Centro Español de Queensland (1926)

Kolonja Polska w Brisbane (Polish Club) (1927)

the House of Israel (1927)

the Hellenic Club of Brisbane (1927)

Der Brisbane Goethe Bund (1927)

Brisbana Esperanto-Societo (1927) ${ }^{4}$

Looking at this list, we might be forgiven for thinking that not much in the way of culture can have been going on in Brisbane before World War I. This would not quite be true, however. As Leanne Day has shown, several literary, artistic and debating societies flourished from the 1880s and into the next century, including the Johnsonian Club, the Brisbane Literary Circle and a handful of smaller literary, dramatic and debating societies. ${ }^{5}$ Although a few of these early formations the Johnsonian, the Irish Club and the Burns Club - survived well into the next century (the Queensland Irish Association is still going strong), most had disappeared by 1914. In that sense, Brisbane really does seem to have had a quite sudden cultural awakening in the 1920s, one that had acquired a distinctly cosmopolitan complexion by the middle of the decade.

If cultural history, cultural studies and common sense have taught us anything in recent decades, it is that such processes do not happen spontaneously, whatever biological and horticultural metaphors may be used to describe and animate them - especially when they happen this quickly. This was a piece of deliberate cultural work. So who was responsible for it, why did they do it and how it was it implemented?

The first question is answerable, but complicated. The key figure in the first half of the decade was undoubtedly Joseph Jeremiah Stable, the first Professor of English at the University of Queensland. He was appointed to that post in 1922, having been a Lecturer in English, French and German for the previous decade. More to the present purpose, he enlisted as an artillery officer in 1916, and was seconded shortly afterwards (aged 33) to the post of Chief Queensland Military Censor. In that capacity, he played a controversial role in the escalating conflict between the federal and state governments over the issue of conscription: in November 1917, acting under instructions from Prime Minister Billy Hughes, he entered the Government Printing Office with an armed escort and confiscated copies of Hansard No. 37, the issue that contained the text of an anti-conscription 


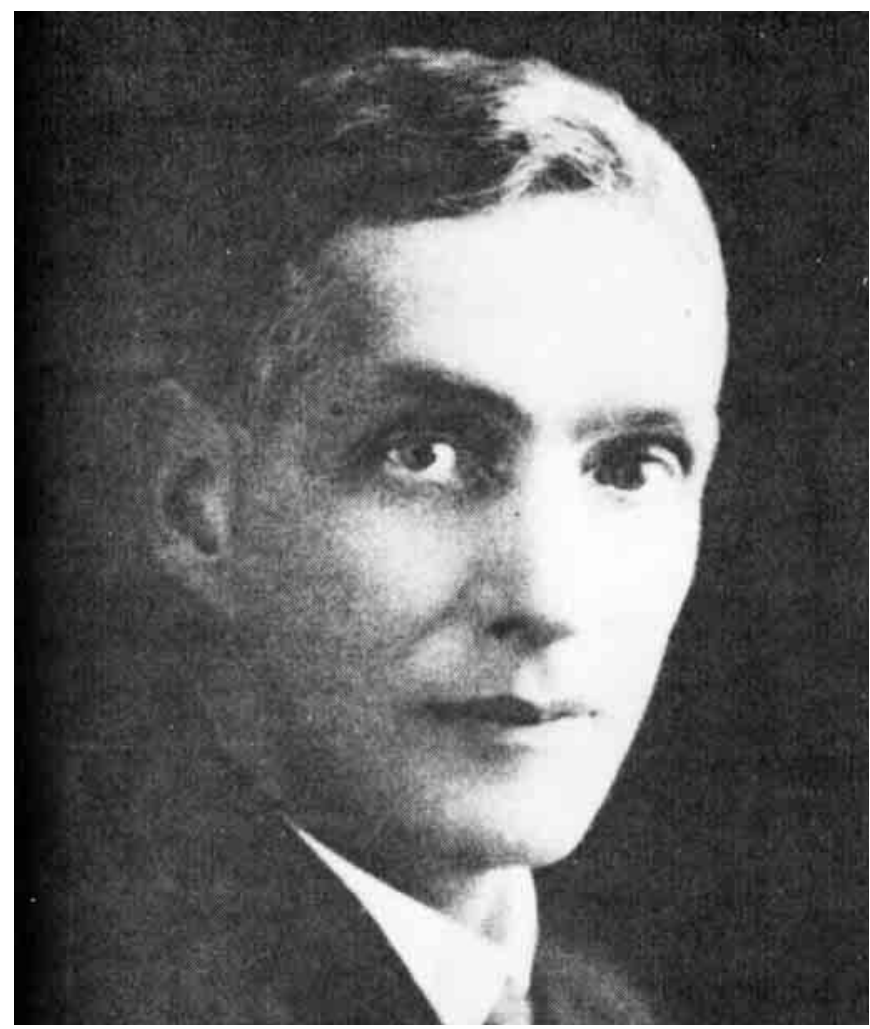

Jeremiah Joseph Stable, c. 1920

speech in the Legislative Assembly by Queensland Premier TJ Ryan, which Stable had earlier censored as tending to promote civil disorder. Several violent clashes had already occurred in Brisbane between trade unionists and returned soldiers, and this episode came perilously close, as Raymond Evans has shown, to precipitating armed conflict between the state police and the army. A year or so later, Stable was again involved in the series of violent anti-Bolshevik demonstrations the so-called 'Red Flag' riots - that culminated in March 1919 in an attack on the Russian Hall in South Brisbane by several thousand ex-servicemen. The returned soldiers were repelled by armed mounted police and the mêlée ended with over a hundred men wounded by bayonets and three police horses shot. ${ }^{6}$

The point of this narrative is to show that Stable had seen the ugly reality of prolonged civil disorder from the inside. Historian Raymond Evans' accounts of the anti-conscription and anti-Bolshevik riots make exciting reading: Stable is on the 'wrong' side in both conflicts, and Evans judges him accordingly. In some respects, however, the judgement seems less than fair. Stable almost certainly favoured conscription and disliked Bolshevism, but there is documentary evidence — Evans cites it himself ${ }^{7}$ — that he also deplored the reckless recourse to violence on both sides, and was unhappy at having to be involved in the Government Printing Office raid. As he wrote in his Censor's report a year later, in the lead-up 


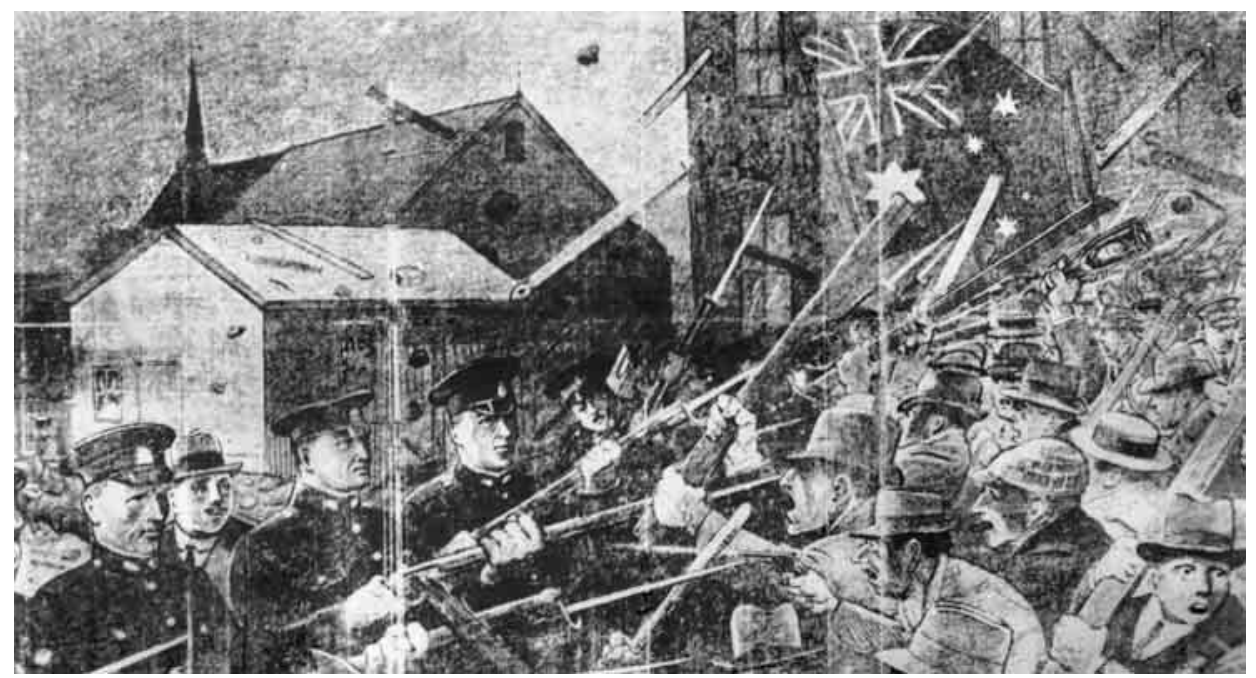

The Red Flag Riots, 1919 (police artist's sketch).

to the Red Flag riots, 'Every second man in the street will prophesy trouble ... some talk as if revolution is a certainty. ${ }^{8}$ It is clear that his overwhelming motive in both conflicts was a strong sense of civic duty, as well as a genuine desire to prevent violence if at all possible.

Seen in this perspective, the crusading zeal with which Stable masterminded the establishment of the Queensland Authors and Artists Association (QAAA) in 1921 assumes a particular significance. In the late 1940s, wags like John Blight, Val Vallis and Judith Wright might - and did - mock the stodgy old Queensland 'Horses and Arses', '9 but in the early 1920s, setting it up was a serious and ambitious attempt to coordinate, aggregate and magnify the power of culture to inspire, unify and - dare one say it? - stabilise a community that, for the last two or three years, had begun to look very much as if it might be spiralling towards anarchy. What was innovative about the QAAA was precisely its breadth - the fact that, unlike most such organisations, it actively encouraged practitioners and consumers of all the art forms to join: painters, sculptors, architects and musicians were as welcome as writers and readers, and the monthly programs of lectures and performances reflect this spread of interests.

Stable's conception of culture was generally Arnoldian, but particularly so in his view of it as a panacea for a society racked by mutual suspicions and warring factions. He certainly saw culture, in Matthew Arnold's phrase, as 'the great help out of our present difficulties'. ${ }^{10}$ He might even, I think, have agreed with Arnold that it 'seeks to do away with classes; to make the best that has been thought and known in the world current everywhere; to make all men live in an atmosphere of sweetness and light'. ${ }^{11}$ However, To the extent that the QAAA was by definition and constitution primarily interested in fostering creative practice across the arts, there were limits to how far it could realise the broader critical and intellectual functions of the Arnoldian ideal. Other, narrower organisations were able to contribute in that way - the Dickens Fellowship and the Brisbane Shakespeare 
Society, for example - and as long as they had the ghost of an interest in literature or the arts, Stable would be there as an office-holder or adviser. He also wrote many of the literary leaders - essentially, mini-lectures in literary history - that were run every Saturday by the Brisbane Courier, and he encouraged members of his staff to do the same. In addition, he agitated publicly for improvements to the Public Library and the Queensland Art Gallery, both of which he considered a disgrace and an embarrassment to Queensland. ${ }^{12}$

What Stable had achieved by the middle of the decade, through his own writing, organisational energy and professional networking, was impressive but while they may have been more wide-ranging, more integrated and more urgent, his projects were not strikingly different from the cultural improvement programs promoted by Reginald Heber Roe, the headmaster of Brisbane Grammar School in the 1890s, which blended an explicitly Arnoldian cultural idealism with the varied formats of the American Chautauquas. ${ }^{13}$

At this stage (1925), two new players entered upon the scene; they would give the project of 'pacifying Brisbane' a new lease of life, making it livelier, more varied and more popular in its appeal than hitherto. The first was Henri Alexis

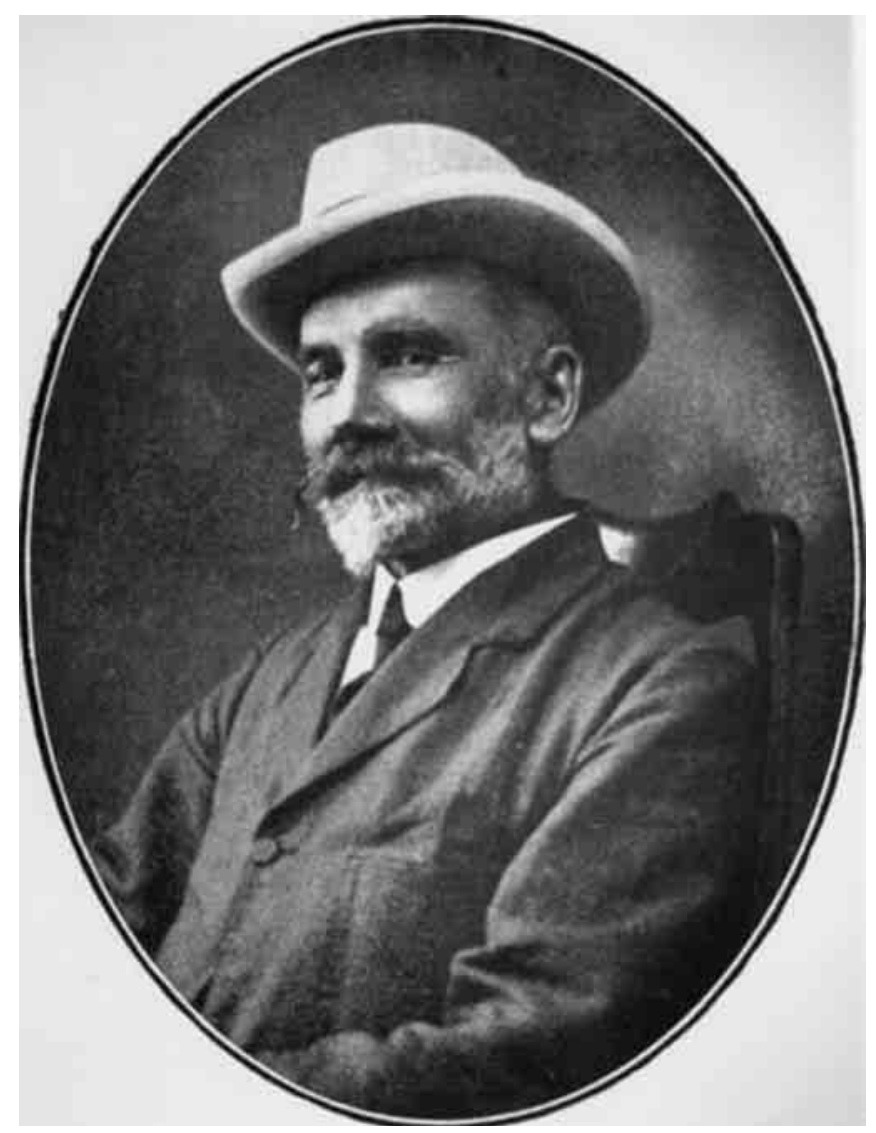

Henri Alexis Tardent, c. 1920. 
Tardent (1853-1929), a Swiss-born polymath educated in Russia, by occupation a horticulturist and former journalist but also a linguist, scientist, art critic, philosopher and social visionary. ${ }^{14} \mathrm{He}$ was also the somewhat better-known 'Inky' Stephenson's maternal grandfather. ${ }^{15}$

Tardent had emigrated with his family to Queensland in 1887, and he lived and worked in various parts of the state, from Atherton to Toowoomba, ending up in Wynnum on the outskirts of Brisbane by the early 1920s. 'Wherever he lived,' Maurice French observes, 'he helped to establish societies with musical, literary, scientific or agricultural interests. ${ }^{16}$ Part of that entrepreneurial streak was his ability to cultivate close relations with political and cultural elites: he was on familiar terms with Sir Samuel Griffith, former Prime Minister Andrew Fisher and, importantly, Sir Matthew Nathan, the state governor from 1920 to 1925, who was an active supporter of many of Tardent's initiatives.

One of Tardent's abiding enthusiasms - hardly surprisingly, given his own background - was the promotion of European languages and cultures in Queensland, which he realised through his leading or enabling roles in the formation of most of the ethnic cultural organisations listed earlier - French, German, Italian, Greek, Polish, Spanish and Jewish - all of which sprang into being in 1926-27. Another enthusiasm was the future of Queensland's home-grown literary, artistic and musical culture, a subject on which he was irrepressibly bullish, and on which he dilated in his own books on individual Queensland painters and poets, and in his work with Stable and the QAAA on the annual Authors' Week programs in Brisbane. His love of horticulture provided him with a large inventory of optimistic metaphors for the variegated outgrowths of culture he saw all around him in the rich soil and temperate climate of sunny Queensland. However, Tardent had a particular love of music, and this is where the third key figure enters the picture.

Luis Amadeo Parés (1893-1948), the son of a Catalonian father and an Australian mother, grew up in Mareeba, left school after Grade 8 and started taking classes from the local violin teacher at the age of sixteen. A year later, he moved to Bowen to stay with his Uncle Amadee, 'a Belgian musician of great ability' who refined his technique by 'overwhelming him with satire' at every opportunity, starting with his 'treacherous vibrato': 'That horrible gna-an-see-orr with which you begin each bow stroke begets notes shaped like giant tadpoles and about as attractive. ${ }^{17}$ Partly in retreat from such stern medicine, Luis and a friend set off through the mining towns and pastoral districts of North, Central and Western Queensland, alternately labouring and performing music in cinemas, theatres, town halls, Schools of Arts and hotels, often with travelling Vaudeville troupes such as the Forti Vaudeville Company and the Luzbel Brothers. Life on the road took its toll: after five years he had a nervous breakdown, and in 1919 married Sarah Lynch, began a family and eventually kept a promise he had made to himself years before by moving to Sydney in 1921 to study privately with Cyril Monk, the eminent Australian violinist at the Sydney Conservatorium. ${ }^{18}$

Parés returned to Queensland, and after a short and miserable stay in Bundaberg and Maryborough, decided that his destiny lay in Brisbane. He arrived at Brunswick Street Station on 31 May 1923, with his wife and two young children and 'funds enough to provide a flat and food for a week', and proceeded to 


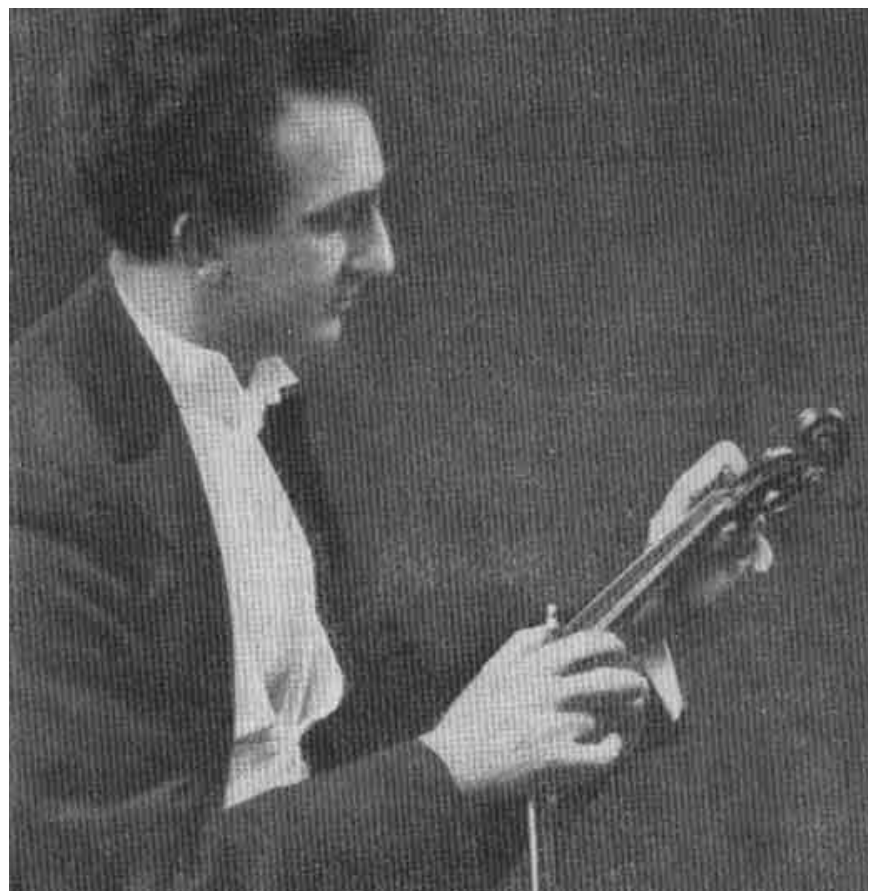

Luis Amadeo Parés, c. 1927.

look for work. At one of his first engagements, a concert at the Manly and Wynnum Choral Society, he met Henri Tardent. As he put it in his chaotic, often hilarious memoir of 1943, I Fiddled the Years Away, Tardent 'attracted me as a magnet draws steel ... a man of Pythagorean wisdom ... another Abou Ben Adhem, who backed his love for his fellow man by a life of service and self-abnegation'. He became 'a dynamic force at my back', encouraging 'the idea of creating a local habitation for music, art and letters in the city ... thus was established the Hall of the Muses'. ${ }^{19}$

It is not quite clear from Parés's account just whose idea the Hall of the Muses was. It was certainly Tardent's type of project, but Parés was himself extremely well read, and possessed of a lively intellect and wide cultural interests: his dozens of letters to the Brisbane Courier over three years (1923-26) provide ample evidence of this, ranging as they do (with considerable eloquence and sophistication) across the history of violin technique to the relations between art and commerce, beauty and truth, ideals and realisation, the nature of contentment, the evolutionary functions of the nervous system and many other matters. ${ }^{20} \mathrm{He}$ would certainly have been an equal partner in the enterprise with Tardent, and in any case, with his flair for publicity, he was the ideal front-man.

The Hall of the Muses was established in late 1925, first in Little Roma Street and later in slightly larger premises at 323 George Street in the centre of the city. It consisted of 'a miniature concert hall, a few studies, an office, an attic, passage way and staircases, all heaped up in each other's way'. ${ }^{21}$ Here Parés conducted his violin lessons, provided meeting rooms for several clubs and societies, and offered 
a refuge for a varied collection of impoverished European bohemians and wanderers, mostly musical - the cleaner, Victor Scalabrini, an occasional singer in Parés's operatic concerts on 4QG; Professor Vladimir Elin, from Petrograd by way of Siam and the Philippines, a fine baritone who used the hall to conduct voice coaching classes and 'to conceal his mistresses from a wronged and irate Siamese spouse'; another Russian singer, Madame Kassovskaia, who claimed to have fought at the head of Kornilov's White Army as the 'Russian Joan of Arc', and who strode the streets of Brisbane in white Cossack boots and a flowery exotic robe; a Hungarian doctor, a Swedish nobleman, a French count (Comte Gontran de Tournouer), and a brilliant young Swiss philosopher and painter whom Parés employed as an amanuensis in return for board at his home in Manly. ${ }^{22}$ During this period, the hall also served, extraordinarily, as the Queensland Bolivian Consulate, Parés having accepted the temporary post of Acting Consul for the Republic of Bolivia in October 1927 on the Comte De Tournouer's recommendation. During the year and a half of his tenure, several consular receptions were hosted there, but only one Bolivian subject was assisted, an Irishman named Murphy. ${ }^{23}$

The premises were also capacious enough to mount regular cultural events of a less fantastic kind - concerts, exhibitions, readings and even plays - and to do it comfortably enough to accommodate the governor or lieutenant-governor and his party, who attended several such events, including the inaugural one. Here Parés describes some of the activities on that occasion:

An Evening with the Muses in the presence of Vice-Royalty, at which nine talented ladies represented the Parnassian sisters, made an auspicious opening to the rooms. Later, in an effort to unite the cultivated people of the various races residing in Brisbane, I arranged an evening at which polished addresses were delivered in thirteen respective languages and afterwards redelivered in English. Here too, as time went on, art displays were held, recitals were given, and Spanish, French, Italian and German literary clubs were domiciled. ${ }^{24}$

The yoking together of classical iconography, 'cultivation' and polyglot ethnic diversity - naïve as it sounds in Parés's account - hints at a complex cultural strategy for neutralising the threat of social conflict inherent in ethnic difference by 'performing' it in exclusively cultural and linguistic forms. These differences are implicitly paralleled, and further distanced and harmonised, by the unity-inmultiplicity of the Nine Muses. It is a novel - if apparently somewhat erudite strategy, but it has a certain logic and coherence, and it does represent an important extension and enrichment of the Anglo-centric pacification project Stable had initiated a few years earlier.

If the establishment of the Hall of the Muses was essentially a collaboration between Tardent and Parés, the next stage in the process was all Parés's work. Every few months since early 1925, he had been presenting musical concerts and soirées in venues in and around Brisbane, including the Elite Theatre in Toowong, the Theatre Royal in the City, the Sandgate and Ipswich Town Halls and several others. These events featured soloists, both instrumental and vocal, together with some verse recitations and orchestral pieces by Parés's own violin students, 
performing in groups of 70 or more. The audiences sometimes included governors, state politicians, mayors, judges and senior academics such as Professor Stable and Dr FW Robinson of the English Department - many of them present, no doubt, with the active encouragement of the well-connected Tardent who, with his wife and daughter, was a regular attendee and occasional performer. ${ }^{25}$ In September 1927, after seven months of intensive recruitment, arrangement and rehearsal, Parés mounted and conducted a remarkable concert in the then Exhibition Hall (now the Old Museum) - a very large space, as it needed to be to accommodate the 1300 violinists, most of them schoolchildren, who, on three successive nights, performed a short program comprising an original composition by Parés (a lullaby, arranged in two parts) followed by the march from Wagner's Tannhäuser. ${ }^{26}$ Against many expectations, the ' 1000 Violins Ensemble', as it was called, was a resounding success. It received enthusiastic reviews in all three Brisbane dailies and the Queenslander, and admiring notices in music journals in Britain, France and the United States; some overseas reviewers had even been able to listen in to a short-wave broadcast of the concert by 4QG. Parés himself was in ecstasies at what he later described as 'the vast, ocean-like waves of music that swelled and sped away like swishing water'. ${ }^{27}$

For others, though, the most sublime aspect of what the Brisbane Daily Mail called 'one of the most outstanding events in the history of music in Brisbane' was its demonstration of the sheer power, not just of the instrumental effect, but of the Maestro himself. The Brisbane Telegraph put it quite baldly: 'Mr Parés has to his credit the remarkable performance of having controlled approximately 1,000 violinists. ${ }^{28}$ But a Mr EA Francis ('Fanuel') may have captured his Promethean magnificence more justly in the following verses. (Parés certainly thought so, and quoted them in his memoir):

A thousand notes that spread a cadence sweet,

A thousand echoes tremble to the skies,

A thousand souls awake to art and greet

The God within their eyes.

And on the stage a towering rugged shade -

With dream-filled eyes and eager nervous beat,

The Maestro guides the rhythm he has made

To God's divine retreat. ${ }^{29}$

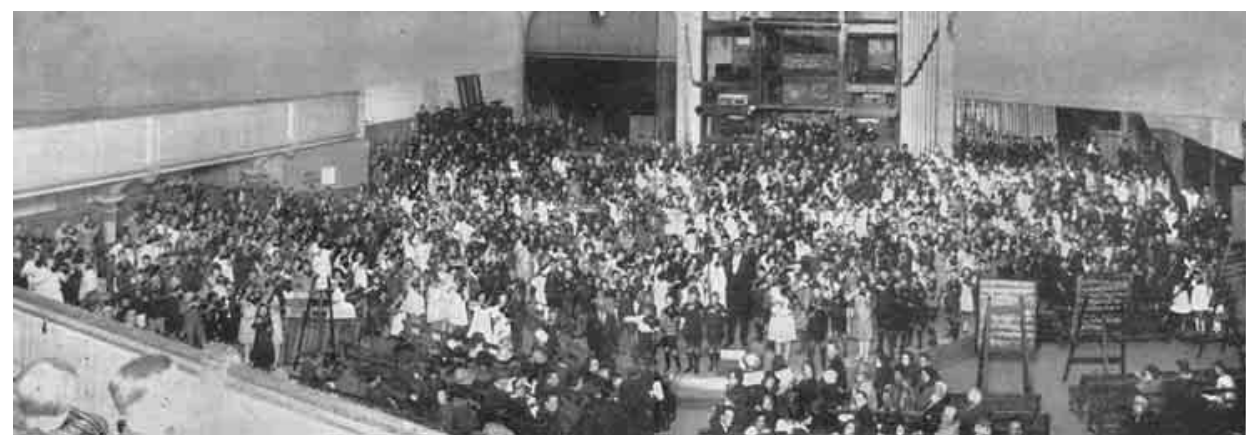

The '1000 Violins Ensemble', August 1927. 
The excitement and interest the event generated made Parés something of a celebrity in Brisbane for a time, not just because of its spectacular scale and originality but also because, in the six months leading up to the event, he offered free violin tuition to as many beginners as were prepared to commit themselves to a regimen of training for the great ensemble. ${ }^{30}$ The gesture won him great kudos, and was remembered in his obituary 21 years later. ${ }^{31}$ Parés himself saw the success of the concert as a vindication of the 'super-optimism' that was the keynote of his personality. It was also a financial bonanza: most of the 6000 tickets printed were sold and, with the commission he received from the Queen Street music retailer WH Palings \& Co. on the sale of 400 new violins, this brought his gross income for the year to $1600 .{ }^{32}$ Much of this was ploughed into various projects associated with the Hall of the Muses, and in particular a new publication, The Muses' Magazine, which made its first appearance in November 1927, just three months after the 'Grand Concert'.

On its masthead, The Muses' Magazine described itself as a 'monthly review of the musical, artistic, literary, and intellectual life of Queensland', and Parés's opening editorial presented it as a stimulus to the innate creativity, intellectuality and talent of Queenslanders:

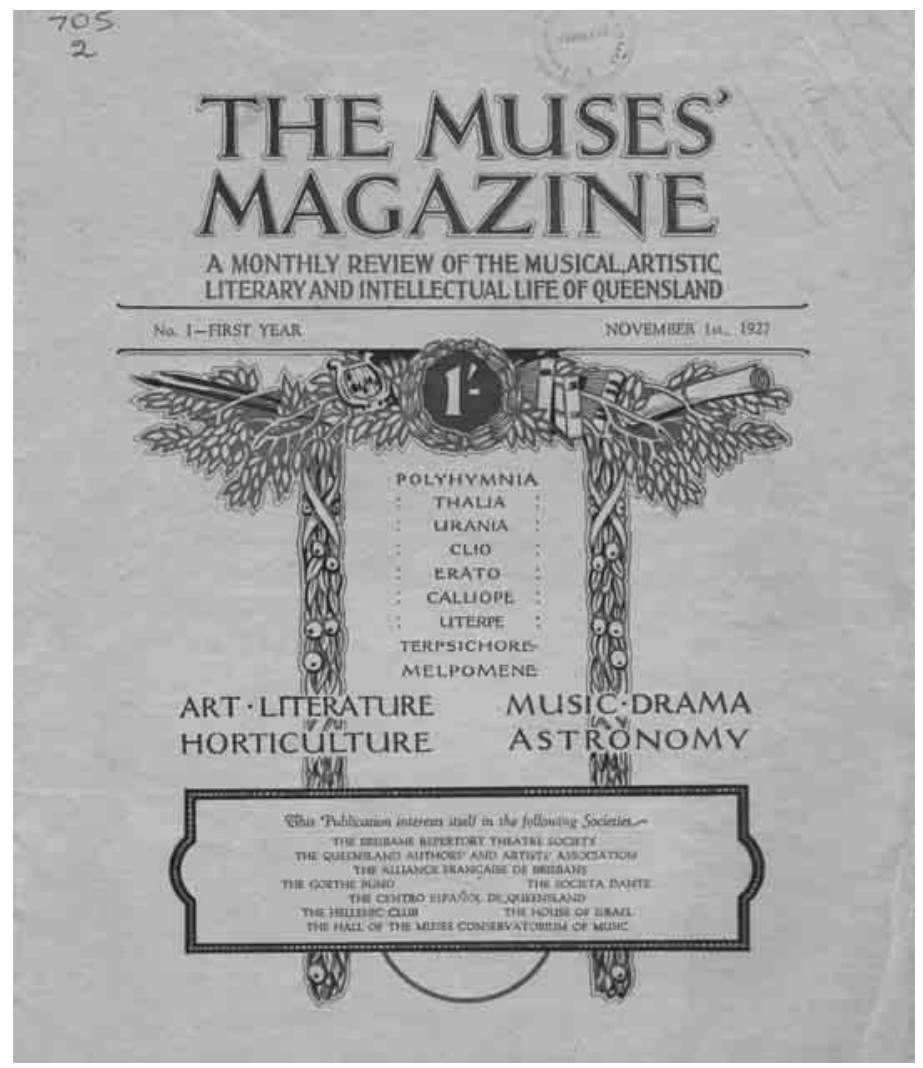

The Muses' Magazine, first issue, November 1927. 
The most casual observer could not fail to notice that there is a rejoicing awakening in the intellectual, musical and artistic life of Queensland. Although materialistic pursuits are predominant in our hustling modern civilization, there is nevertheless in our midst a very fair proportion of intellectual workers, who keep proudly flying the flag of idealism. Talent abounds in our people, although up to now it has received but scanty recognition and encouragement. It truly seems as if our sunny skies and pellucid atmosphere were, like those of ancient Greece, favourable to the production of talent. To the solid qualities inherited from our vigorous ancestral stock, we add something new: the cheerfulness, the joie de vivre, so characteristic of the nations living in sunny lands.

The cheery opening note of Queensland exceptionalism modulates seamlessly into a celebration of national scientific and technological modernity, an insistence on 'our' world-historical entitlements ('As a young nation we claim access to all the civilizations and literatures that have preceded us ...'), and a proper reverence for the institution that secured that access and disseminated its fruits:

Our young University is a fecund nursery of energetic and learned professors, who are not only able exponents of the sciences which they are teaching, but take also a very active part in the intellectual life of the community...

But the magazine's central claim - like that of the Hall of the Muses that gave birth to it - was that it gave a voice to Brisbane's contemporary cultural diversity, a claim borne out in the list of contributors to this and subsequent issues, as well as in the list of affiliated organisations on the front cover, to which the editor drew special attention:

A glance on the cover of this Magazine will disclose the fact that among all the Australian cities Brisbane has the largest number of societies devoted to the study of foreign languages and literatures.

The cover does not in fact exactly substantiate this slightly surprising claim (though it may well be true), but among the affiliates it does list six organizations of that kind (French, German, Greek, Italian, Spanish and Jewish), and later these were joined by the Polish and Esperanto Societies. The value placed upon the multicultural aspiration was the important thing, and it certainly radiated an attitude not just of tolerance, but of interest and enthusiasm, towards non Anglo-Celtic cultures and languages.

The Muses' Magazine ran for only fourteen monthly issues, from November 1927 to January 1929, but in its short life it exhibited several remarkable features. It was quite lavishly produced, with up to half a dozen colour reproductions of botanical paintings, by (the late) Ellis Rowan and Phoebe Kirwan, among others. This partly reflected Tardent's interests (he had written a book on Rowan), but women were also strongly represented in their own right as authors, especially poets. Every issue contained poems and essays by the best-known Queensland poets of the day, most of whom were women - Mabel Forrest, Emily Bulcock, EM England, Annie Powis Dunn, Margaret Curran and Doris Waraker - and some original poems in untranslated Italian, German, Greek and French. About halfway through its run, the magazine opened a special poetry section called 'The 
Pages of Calliope and Erato' (the Muses of epic and lyric poetry), edited from Canberra by RA Broinowski, Usher of the Black Rod in the Australian Senate, which attracted nationwide and even some overseas contributions. In most issues there was also an original ode to one of the Muses (again helping to reinforce the magazine's founding trope) by the eminent translator of classical Chinese poetry, WJB Fletcher, then British Consul at Hoihow in China. Like the women poets, he contributed essays as well, mainly on Chinese subjects.

Most of the content consisted of essays - many of them quite scholarly, but appropriately pitched for a well-read general readership - on a range of topics, from the great European literatures (Russian, German, French, Italian, but also the less familiar: Finnish, Swedish, modern Greek, ancient Chinese), to art, architecture and society; literature, philosophy and psychology; recent, modern and ancient history; science (particularly botany, meteorology and astronomy), and much else. Inigo Jones, the long-range weather forecaster, appeared in more than half the issues. Like Henri Tardent, Jones was a polymath; his essays dealt, engagingly enough, with rainbows, planets and sunspots on the one hand, and Dickens, Shakespeare and Rosa Praed on the other.

All this was cheerfully presented in the name of cosmopolitan cultivation, but at several points the more sensitive motive of postwar pacification was acknowledged, together with the need to use universal culture to counteract the post-war residues of bitterness and suspicion. HG Tommerup, a Lecturer in German at the university, in speaking of the role of 'foreign associations' like the newly established Goethe Bund, expresses this awkwardly but revealingly:

There is still a great deal of misunderstanding about them ['foreign associations'] in our midst, and consequently prejudice against them. Those at any rate which profess to be 'cultural' — i.e. absolutely nonpolitical — are really British, and not foreign. A foreign language is of course also spoken at their meetings: but so too is English: and if a foreign language is taught there, so is English also. Alien 'purpose' does not, strictly speaking, exist: alien thought is studied, and alien sympathy is aroused, but only for the purpose of bringing a better understanding and a friendlier feeling. ${ }^{33}$

Even more noticeable than the multiculturalism of the magazine is its preoccupation with music. In one way, this is hardly surprising. Parés himself was first and foremost a practising musician, after all, and he ensured that the music scene in Brisbane was covered comprehensively. But the 'musicality' of the magazine is not just a matter of the many reviews of musical events in every issue. It also has to do with the large number of historical, analytical and speculative articles about music (by George Sampson, Parés himself, Jerome Bell, Stefan de Polotynski and several anonymous academics), the snappy paragraphs of interesting musical facts and thoughts (technical, historical and philosophical), the plethora of music retailing advertisements and the reproduction of the Queenslander's flashlight photograph of the ' 1000 Violins' concert on the back flyleaf of every issue. And it has to do with a certain 'musicalisation' of the discourse of the whole journal, such that even essays and stories about non-musical subjects somehow contrive to focus on their musical aspects, or to consider them from a quasi-musical point of view. In the first issue, Stable's first article, 'Music in Poetry', and Mabel Forrest's 
prose piece, 'Bush Music', are straightforward examples, ${ }^{34}$ but there are other, more oblique, instances - Tardent on the contemporary use of English, for example, where the degradation of language is analysed in terms of the corruption of musical taste. ${ }^{35}$ Short stories (by EM England and Annie Powis Dunn), travel pieces, botanical essays, art appreciations, historical narratives and poems mostly seem able to find musical angles, analogies or just metaphors with noticeable frequency. It is almost as if the contributors were responding to an expectation that they should all at least try, in whatever way they could, to 'aspire to the condition of music'.

What impulse lay behind this tendency to integrate the social and cultural diversity of Brisbane through the lens of music? When placed in the context of an ongoing project to pacify Brisbane - to acknowledge and celebrate, but above all harmonise, the class and ethnic differences that had proved threatening to civil order less than a decade earlier, the rationale is obvious: as William Congreve put it, 'Music has charms to soothe the savage breast'. ${ }^{36}$ Since ancient times, philosophers have believed that music can work as an instrument for producing both individual and social harmony, and in 1926 Frank Howes, the regular music critic of the London Times, published a book that sought to ground that belief in a modern psychological analysis of emotional responses to music and of the nature of musical pleasure. ${ }^{37}$ The later issues of The Muses' Magazine are liberally sprinkled with disconnected 'morceaux' (so called) taken directly from Howes' book, The Borderland of Music and Psychology - clearly a recent enthusiasm of Parés — in which these matters are explored in a straightforward and engaging style. ${ }^{38}$

The following passage, which deals with the meaning of applause, is one of about half a dozen that appeared:

The amount of applause after any number in a concert programme is determined not by the depth of feeling or the intensity of the pleasure experienced by the audience but by the homogeneity of the feeling, i.e. by the number of persons who experience a similar enthusiasm for the same piece of music. Hearty applause indicates that some considerable amount of group feeling has been generated, and must not be regarded as a sign of any profound stirring of emotion, still less of the delivery of a critical judgment on the listeners' part. The truth of this statement may be confirmed by a consideration of the kind of music which receives most applause. ${ }^{39}$

These and other passages from Howes' book focus on the group dimension of the musical experience, and when juxtaposed with other 'morceaux' drawn from contemporary studies of crowd behaviour, such as Gustave Bon's The Crowd (1922), evince a strong impulse on Parés's part to think through in quite sophisticated ways the relevance of music itself, and of musical models and analogies, to an understanding of social and political behaviour. Bon's discussion of charismatic 'hero effects' in crowd contexts includes observations such as:

The crowd cannot get on without a hero in the sense of a representative man, and upon him, who is thus only a personification of itself, it pours out its veneration. And so when at a concert a popular contralto sings a song of the kind which is itself a crowd-phenomenon, she becomes the idol 
of the audience, the crowd-representative, upon whom all its thwarted selfesteem descends in the form of hero-worship. ${ }^{40}$

It is difficult not to suspect that such an analysis would have struck Parés as fairly directly applicable to his own recent performances as Maestro of the ' 1000 Violins', except that where Gustave Bon's language conveys a critical perspective on the phenomenon, Parés - at least by implication - seems to offer it rather as a benevolent emotional substitute for mass disorder and violence. The iconic significance of the photograph of the Grand Ensemble for the whole project of The Muses' Magazine thus becomes clearer - if also, in retrospect, a little worrying in its ideological tendency.

If, as that last sentence intends to hint, the social perspective of the magazine were informed, at least in its later issues, by a certain streak of 'proto-fascism', it would not be a surprising finding. The last few issues publish several articles that exhibit a eugenicist tendency (JP Lowson on the treatment of delinquency, for example), ${ }^{41}$ and Mussolini is referred to several times in neutral or favourable terms. ${ }^{42}$ It is clear, more broadly, that the regular authors constitute an elite of sorts - a cultural and intellectual elite rather than a social or political one, though inevitably there is some overlap: several of the senior academic contributors (Professors Stable, Michie and Cumbrae-Stewart, for example) turned up at Government House soirées, as did some of the non-Anglo contributors (such as Christie Freeleagus and the Comte de Tournouer), since they held diplomatic posts of one kind or another. It is, in short, the kind of group - culturally diverse though it certainly was - to whom benevolent, but (in hindsight) identifiably proto-fascist solutions to the problem of social disorder came fairly naturally.

The whole enterprise came to an end rather abruptly. Parés asserts in his memoir that trumpeting the success of their first year in the first issue of their second brought his creditors down upon him, forcing him into bankruptcy. ${ }^{43}$ That may be true - and the proceedings against him in the Bankruptcy Court seem to confirm it ${ }^{44}$ - but an equally disabling event would probably have been Tardent's worsening health. He died in September 1929, and the 'Muses' phenomenon both hall and magazine - seems to have died with him. Whether the 'super-optimism' of its mission would have survived the sharpened class conflicts of the Great Depression and the rise of Hitler is in any case doubtful.

\section{Acknowledgments}

Acknowledgments to the State Library of Queensland for Figures 2, 3, 5 and 6.

\section{Endnotes}

1 Accounts of this period in Queensland history can be found in Ross Fitzgerald, From 1915 to the Early 1980s: A History of Queensland (St Lucia: University of Queensland Press, 1984), pp. 14-41, and Raymond Evans, A History of Queensland (Melbourne: Cambridge University Press, 2007), pp. 159ff. Despite their own differences of approach and emphasis, neither Fitzgerald nor Evans accords the same social, political and cultural distinctiveness to the 1920 s that the present article proposes. 
2 ABC of Queensland and Australian Statistics 1927 (Brisbane: Registrar-General, Queensland, 1927), p. 96; ABC of Queensland and Australian Statistics 1934 (Brisbane: Registrar-General, Queensland, 1934), p. 144.

3 Not to be confused with the Società Dante Alighieri (Dante Alighieri Society), the international organisation founded in Rome in 1889. Official branches of the DAS were established in Melbourne in 1896 and Sydney in 1925, but not in Brisbane until 1937. Based on the information contained in several issues of The Muses' Magazine, it seems clear that the 'Dante Society' that was formed in 1926 (with Archbishop Duhig as patron, HG Tommerup as president, and JJ Stable as vice-president) was quite separate from the later Dante Alighieri Society branch. I do not know whether it still existed in 1937.

4 The list is compiled from several sources, including HA Tardent, 'Linguistic Study in Brisbane', The Muses' Magazine, 11 (September 1928): 1, and Multicultural Queensland: 100 Years, 100 Communities: A Century of Contributions, ed. Maximilien Brändle (Brisbane: Multicultural Affairs Queensland, 2001).

5 Leanne M Day, 'Civilising the City: Literary Societies and Clubs in Brisbane During the 1880s and 1890s', unpublished PhD thesis, Griffith University, 2005.

6 Raymond Evans, 'Conscription Riot', 'Government Printing Office, 1917', 'Red Flag Riots, 1919', in Radical Brisbane: An Unruly History, eds Raymond Evans and Carole Ferrier, with Jeff Rickertt (Melbourne: Vulgar Press, 2004), pp. 156-74. See also Evans, The Red Flag Riots: A Study of Intolerance (St Lucia: University of Queensland Press, 1988).

7 See, for example, Stable's urgent cable to Prime Minister Hughes on the eve of the Government Printing Office raid: 'Is there any way of preventing this other than by armed force?' In response, Hughes arrived in Brisbane the next day and personally directed the first of the raids by the army. There seems no doubt that Hughes, unlike Stable, was eager for violence: three days later, he responded to eggs being thrown at him during a speech in Warwick by leaping into the crowd, 'reaching inside his overcoat for a revolver fortunately left behind in another coat in the railway carriage - astonishing those watching with his "wildly infuriated manner". Evans, Radical Brisbane, pp. 164, 162.

8 Evans, Red Flag Riots, p. 83.

9 Patrick Buckridge, 'Roles for Writers: Brisbane and Literature, 1859-1975', in By the Book: A Literary History of Queensland, eds Patrick Buckridge and Belinda McKay (St Lucia: University of Queensland Press, 2007), p. 61.

10 Matthew Arnold, Culture and Anarchy, ed. J Dover Wilson (Cambridge: Cambridge University Press, 1960), p. 6.

11 Arnold, Culture and Anarchy, p. 70.

12 JC Mahoney, 'Stable, Jeremiah Joseph (1883-1953)', Australian Dictionary of Biography, Vol. 12 (Melbourne: Melbourne University Press, 1990), p. 42; 'Queensland Authors and Artists Association', The Muses' Magazine, 11 (September 1928): 19.

13 E Clarke, 'Roe, Reginald Heber (1850-1926)', Australian Dictionary of Biography, Vol. 11 (Melbourne: Melbourne University Press, 1988), pp. 437-9; Day, Civilising the City, pp. 26-69.

14 M French, 'Tardent, Henry Alexis (1853-1929)', Australian Dictionary of Biography, Volume 12, (Melbourne: Melbourne University Press, 1990), pp. 167-8.

15 Craig Munro, Inky Stephenson: Wild Man of Letters (St Lucia: University of Queensland Press, 1992), pp. 4-5.

16 French, 'Tardent', p. 168.

17 Luis Amadeo Parés, I Fiddled the Years Away (Brisbane: Author, 1943), p. 34.

18 Parés, I Fiddled the Years Away, p. 61.

19 Parés, I Fiddled the Years Away, p. 79. 
20 Brisbane Courier, 15 November 1923: 13; 6 November 1924: 12; 22 May 1924: 16; 4 July 1925: 12; 10 July 1924: 12; 19 June 1924: 13.

21 Parés, I Fiddled the Years Away, p. 106.

22 Parés, I Fiddled the Years Away, p. 110.

23 Parés, I Fiddled the Years Away, p. pp. 83-6. See also Brisbane Courier, 13 March 1929, p. 16.

24 Parés, I Fiddled the Years Away, p. 80.

25 Reports on some of these events can be found in the Brisbane Courier, 7 February 1925: 5; 2 May 1925: 17; 6 May 1925: 12; 19 September 1925: 11.

26 The score of the lullaby, La Cuna [Cradle Song], composed by LA Parés, with words by CA Neville, can be viewed online in the State Library of Queensland collection.

27 Parés, I Fiddled the Years Away, p. 93.

28 Both comments are quoted in the first issue of The Muses' Magazine, 1 (November 1927): 32.

29 Parés, I Fiddled the Years Away, p. 95. The poem was also published in The Muses' Magazine, 4 (February 1928): 16.

30 It was not totally original. A similar attempt had been made in England in 1911, resulting in a performance by over 1000 schoolchildren at the Crystal Palace, London. (On that occasion, as the Courier pointed out, the children were all 'pupils of teachers who were paid for their services', which served to highlight Parés's generosity and vision. Brisbane Courier, 5 March 1927: 26.

31 Brisbane Courier, 4 May 1948: 4.

32 Parés, I Fiddled the Years Away, p. 90.

33 HG Tommerup, 'In Aid of Culture', The Muses' Magazine, 1 (November 1927): 26.

34 The Muses' Magazine, 1 (November 1927): 3ff., 6ff.

35 The Muses' Magazine, 2 (December 1927): 1.

36 The phrase (often misquoted with 'beast' instead of 'breast') comes from William Congreve's tragedy, The Mourning Bride, Act I, Scene 1.

37 Both Tardent and Parés evince a keen interest in the psychology of musical experience. In addition to the 'morceaux' from Frank Howes' book, there is a similar number of quotations on the same subject by the aesthetician Vernon Lee [Violet Paget]. Lee's chief work on the psychology of music, however, first appeared in 1932, and the source for the many quotations from her work in 1928 is something of a mystery.

38 Frank Howes, The Borderland of Music and Psychology (London: Kegan Paul, 1926). For Howes' career, see Diana McVeagh, 'Howes, Frank Stewart (1891-1974)', Oxford Dictionary of National Biography (Oxford: Oxford University Press, 2004).

39 The Muses' Magazine, 12 (November-December 1928): n.p.

40 The Muses' Magazine, 12 (November-December 1928): n.p.

41 The Muses' Magazine, 2 (December 1928): 17.

42 For example, Tommerup, 'In Aid of Culture': 26.

43 Parés, I Fiddled the Years Away, p. 96.

44 Brisbane Courier, 13 March 1929: 16. 